\title{
Analyzing the Removal Effect of Nitrogen before and after Enhanced Aeration in Constructed Wetlands
}

\author{
Hao Wang ${ }^{1 *}$, Xiaoqing An ${ }^{1}$, Yang Yang ${ }^{1}$, Guozhu Bo ${ }^{1}$, \\ Yaozong Zhang ${ }^{2,3}$ \\ ${ }^{1}$ College of Civil and Architectural Engineering, North China University of Science and Technology, \\ Tangshan, P.R. China \\ ${ }^{2}$ Tangshan City Drainage Co., Ltd., Tangshan, P.R. China \\ ${ }^{3}$ Drainage Engineering Technology Research Center of Tangshan City, Tangshan, P.R. China
}

Received: 19 January 2016

Accepted: 18 April 2016

\begin{abstract}
In this research, constructed wetlands were applied to remove the nitrogen of lightly polluted wastewater from a wastewater treatment plant in Tangshan. The results showed that a favorable removal effect of nitrogen could be obtained through constructed wetland. Moreover, the aeration device added to the bottom could increase the removal rates of ammonia nitrogen in lightly polluted wastewater, but the removal of total nitrogen was not satisfactory under this operational condition. In addition, when the bottom aeration device was added, the optimal operation condition was evaluated by three-dimensional (2D and 3D) contour plots. The results showed that in a horizontal zeolite subsurface constructed wetland (HZSW), the optimal removal rates for ammonia nitrogen (which could reach above $98 \%$ ) were obtained when the average daily aeration time was about $7-17 \mathrm{~h}$ and hydraulic loadings were $0.05-0.20 \mathrm{~m}^{3} /\left(\mathrm{m}^{2} \cdot \mathrm{d}\right)$. Meanwhile, the optimal removal rates of total nitrogen could reach $56.40-62.60 \%$ when the average daily aeration time was less than $5 \mathrm{~h}$ and the hydraulic loadings were less than $0.11 \mathrm{~m}^{3} /\left(\mathrm{m}^{2} \cdot \mathrm{d}\right)$. In contrast, in a horizontal limestone subsurface constructed wetland (HLSW) the optimal removal rates of ammonia nitrogen (namely 96.44-97.10\%) could be obtained when the average daily aeration time was more than $11 \mathrm{~h}$ and hydraulic loadings were about $0.10-0.45 \mathrm{~m}^{3} /\left(\mathrm{m}^{2} \cdot \mathrm{d}\right)$; meanwhile, the optimal removal effects of total nitrogen, namely $49.25-55.00 \%$, were obtained when the average daily aeration time was less than $8.5 \mathrm{~h}$ and the hydraulic loadings were less than $0.13 \mathrm{~m}^{3} /\left(\mathrm{m}^{2} \cdot \mathrm{d}\right)$. In summary, the removal effects of ammonia nitrogen increased obviously and that of total nitrogen were depressed apparently after the bottom aeration device was added.
\end{abstract}

Keywords: constructed wetland, nitrogen, bottom aeration, average daily aeration time, hydraulic loading

*e-mail: wanghao1689@gmail.com 


\section{Introduction}

In the last two decades, constructed wetlands (CWs) have turned out to be an efficient ecological technology for the treatment of various kinds of polluted waters [1-4]. The advantages of CWs over other conventional treatment systems are lower costs and easier operation and maintenance [5-6]. Constructed wetlands treatment technology has been given the measure of standard methods in a multitude of countries because of the requirement for low-carbon, environmentally friendly technologies [7-8].

However, the wastewater removal effect of major pollution in a constructed wetland would decrease in quite a few cold districts [9-10]. Therefore, some methods have been applied for solving the bottleneck problems [11]. Artificially enhanced aeration went a good way to increase the dissolved oxygen (DO) in the interior of constructed wetlands and, as a consequence, increasing the removal effect for major pollution [12-14]. Artificially aerated CWs (AACW) can increase oxygen the transfer rate of $160 \mathrm{~g} \mathrm{~m}^{-2} \mathrm{~d}^{-1}$ by compressing air from the atmosphere into the wetland bed with the use of a blower [15]. Most conventional CWs fail to fulfill this first step due to insufficient oxygen supply. Hence, oxygen supply is the key issue to enhancing nitrogen removal in CWs, and artificial aeration is the most effective alternative to guaranteeing sufficient oxygen supply. In particular, when dealing with high-strength wastewater, artificial aeration seems to be the only option to achieve complete nitrification. However, with the enhanced oxygen supply, denitrification usually becomes the limiting step for effective TN elimination due to the lack of an effective anoxic zone and the depletion of the influent carbon source [16-18]. Consequently, TN removal might still not be desirable even if nitrification has been well conducted. Hence, alternative wetland configuration and operational strategies are requested for efficient denitrification in aerated CWs.
Meanwhile, the primary purpose of the current study was to achieve a high rate of nutrient removal from high-strength wastewater with a horizontal subsurface constructed wetland (HSCW) system. In this study, the oxygen aeration tubes were fixed at the bottom of the constructed wetland, and the changed trends of major eutrophication pollutants and operational parameters in constructed wetlands were analyzed under intermittent aeration and optimum aeration conditions, respectively.

\section{Materials and Methods}

\section{Subsurface Wetland Systems}

Our experiment was carried out in a laboratory with a controlled environment in Tangshan of P. R. China. The horizontal subsurface wetland systems consisted of two $1 \mathrm{~m}^{2}$ wetland mesocosms $(1.6 \mathrm{~m}$ length $\times 0.6 \mathrm{~m}$ width $\times 0.6 \mathrm{~m}$ depth). Gravel with a particle diameter of $15-25 \mathrm{~mm}$ was laid at the bottom of the two systems, and the depth was $0.10 \mathrm{~m}$. Zeolite and limestone were laid respectively at the middle layers of the two wetlands - both with particle diameters of $6-10 \mathrm{~mm}$ and depth of $0.20 \mathrm{~m}$. The upper beds consisted of lytag with a depth of $0.15 \mathrm{~m}$ and particle diameter of 3-5 $\mathrm{mm}$. The sieving soils were laid at the uppermost layers, the depth of which was $0.05 \mathrm{~m}$. Phragmites sp. and cattail sp. were planted in the soils with interplanting ratio of $1: 1$, and the plant densities were 48 plants $/ \mathrm{m}^{2}$ and 50 plants $/ \mathrm{m}^{2}$, respectively. The horizontal zeolite subsurface wetland would be represented by HZSW and horizontal limestone subsurface wetland by HLSW in the following parts of this paper. The schematic diagram of the main apparatus is shown in Fig. 1.

In the horizontal direction, the constructed wetland was divided into pre-aeration district, influent buffer district, the main district of the constructed wetland, effluent buffer district, and drainage district. Large-sized zeolites were filled in influent and effluent buffer district (particle size of

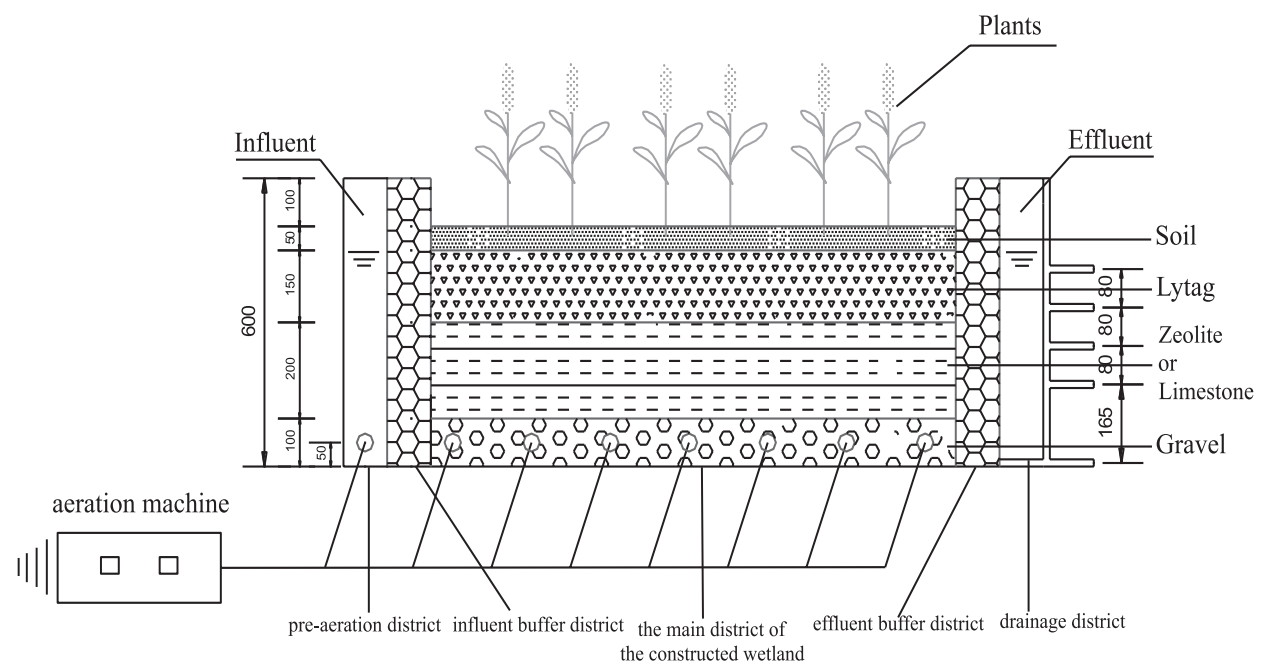

Fig. 1. Schematic diagram of the main apparatus. 
10-15 mm), accordingly ensuring uniform inlet and outlet. Raw water flowed into the pre-aeration buffer district from the top of the influent buffer district, and the main flow flowed through the main district of the constructed wetland, afterward flowing out from the bottom of the effluent buffer district and eventually into the drainage district. In addition, aeration tubes were installed in the pre-aeration district with a height of $0.05 \mathrm{~m}$. In the gravel layer of the main district of the constructed wetland, the aeration tubes were also evenly distributed with a height of $0.05 \mathrm{~m}$ in the same way and aeration tube diameters were about $10 \mathrm{~mm}$.

\section{Influent Quality}

Raw wastewater was collected from the wastewater treatment plant in Tangshan. The composition of the influent used in all experiments is shown in Table 1.

\section{Methodology}

In the experiment, the quality of influent met the standards for secondary-treated wastewater of a sewage treatment plant in China, and samples were collected intermittently. During the aeration phase, system operation time was divided into five periods according to the daily aeration time, and every period was five days. Meanwhile, the average daily aeration time was $4 \mathrm{~h}, 8 \mathrm{~h}, 12 \mathrm{~h}, 18 \mathrm{~h}$, and $24 \mathrm{~h}$, respectively. In addition, the $2 \mathrm{D}$ and $3 \mathrm{D}$ contour plots were carried out using OriginPro 8.0.

In the case of atmospheric temperature decreases, the removal of various pollutants has declined in the constructed wetlands. At this time, according to wetland simulation system design features, the bottom aeration device was added in the two constructed wetlands, and the bottom aeration device consisted of aeration machine, aeration connector tubes, control valves, and preinstalled aeration ports. The aerator model number was LP-40, and aeration rate was of $50 \mathrm{~L} / \mathrm{min}$. Meanwhile, aeration connector tubes were made of plastic with a diameter of $10 \mathrm{~mm}$, and plastic control valves were used, too. Preinstalled aeration ports were being installed when the constructed wetlands were built, and which connected a few plexiglass tubes that spanned the width of the constructed wetlands. For the purpose of uniform aeration,

Table 1. Characteristics of the wastewater sample used in the experiments.

\begin{tabular}{|c|c|c|}
\hline Parameter & Unit & Concentration \\
\hline $\mathrm{pH}$ & - & $6.5-8.0$ \\
\hline $\begin{array}{c}\text { Chemical Oxygen Demand } \\
(\mathrm{COD})\end{array}$ & $\mathrm{mgL}^{-1}$ & $31.6-81.1$ \\
\hline Ammonia Nitrogen $\left(\mathrm{NH}_{3}-\mathrm{N}\right)$ & $\mathrm{mgL}^{-1}$ & $9.5-11.7$ \\
\hline Total Nitrogen $(\mathrm{TN})$ & $\mathrm{mgL}^{-1}$ & $15.7-21.1$ \\
\hline Total Phosphorus $(\mathrm{TP})$ & $\mathrm{mgL}^{-1}$ & $0.89-1.22$ \\
\hline
\end{tabular}

many pores (each with a diameter of $3 \mathrm{~mm}$ ) were evenly distributed across every tube.

\section{Results and Discussion}

\section{Removal Effect of Nitrogen before and after Aeration}

As shown in Fig. 2, the two horizontal flow-constructed wetlands exhibited favorable removal effects of ammonia nitrogen under different average daily aeration times, and the removal rates were maintained at more than $92 \%$. The removal of ammonia nitrogen gradually increased in the HLSW as average daily aeration time went by. By contrast, when average daily aeration time was $8 \mathrm{~h}$, the HZSW exhibited the optimal removal rate with a value of $99.3 \%$ for ammonia nitrogen. Meanwhile, under the conditions of no aeration, the average removal rates for ammonia were $90.7 \%$ at HZSW and $80.3 \%$ at HLSW, respectively. As could be seen from the above data, adding the bottom aerator has a significant impact on ammonia nitrogen removal efficiency of the horizontal flow constructed wetland, and the value of removal rate apparently increased in HLSW.

As shown in Fig. 3, the removal of total nitrogen in two horizontal subsurface flow constructed wetland systems decreased and then increased under different average daily aeration times. After the bottom aeration device was added, the average removals in the horizontal subsurface flow wetland system for TN removal effect were obviously reduced compared to no aeration. Meanwhile, the minimal removal rates for total nitrogen of HZSW and HLSW were $9.6 \%$ and $8.4 \%$, and the optimal removal rates were $65.0 \%$ and $65.7 \%$, respectively. Compared with no aeration, the average removal rates of total nitrogen in HZSW and HLSW were, respectively, $85.7 \%$ and $77.1 \%$, which were much higher than after aeration. The above data

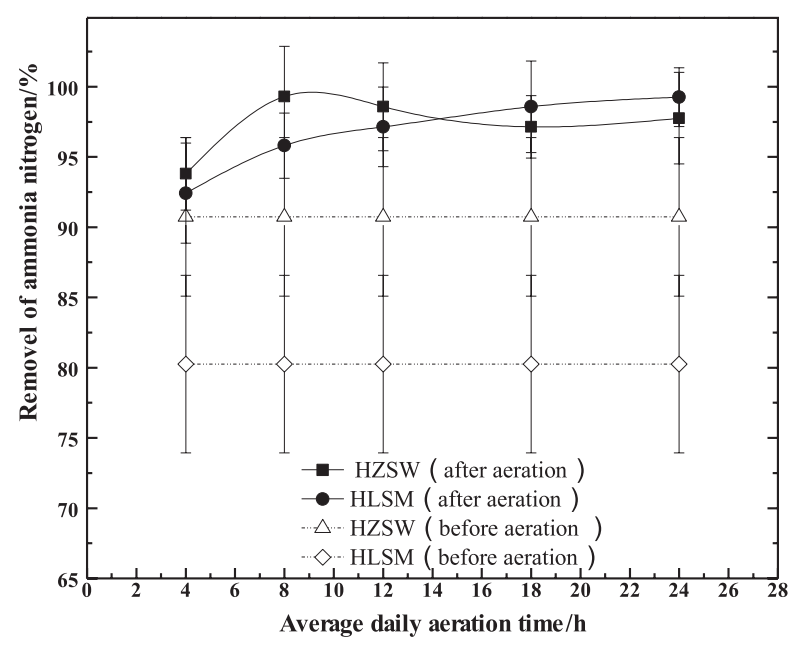

Fig. 2. Aeration effects in relation to removing ammonia nitrogen in horizontal subsurface wetlands. 


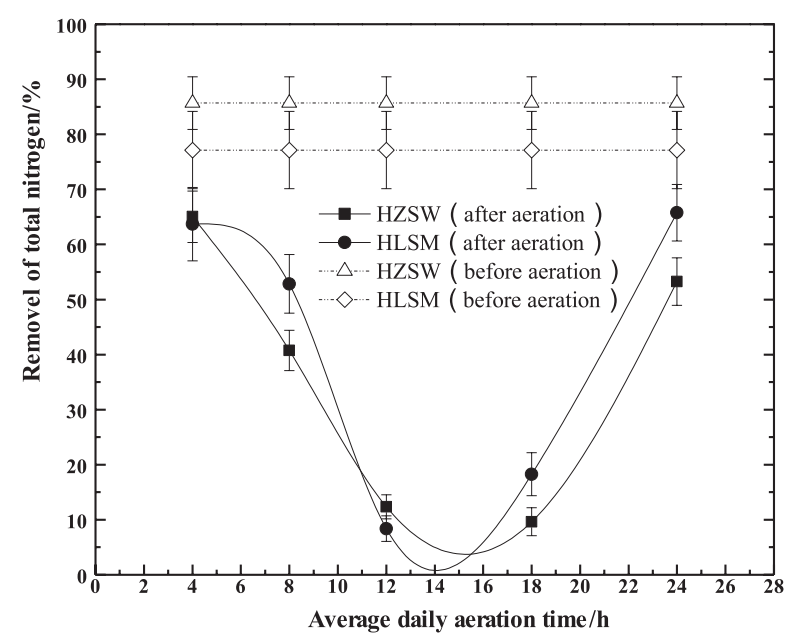

Fig. 3. Analysis of aeration effects in relation to removing total nitrogen in horizontal subsurface wetlands.

showed that the added bottom aeration device served the negative function of removal rates for total nitrogen. The main reason may be that dissolved oxygen concentration inside the wetlands increased obviously, which induced

a)

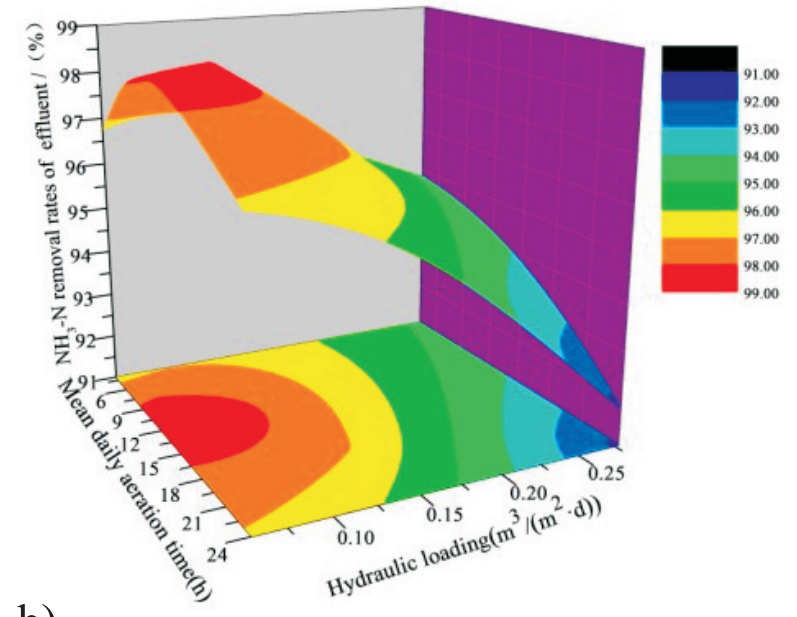

b)
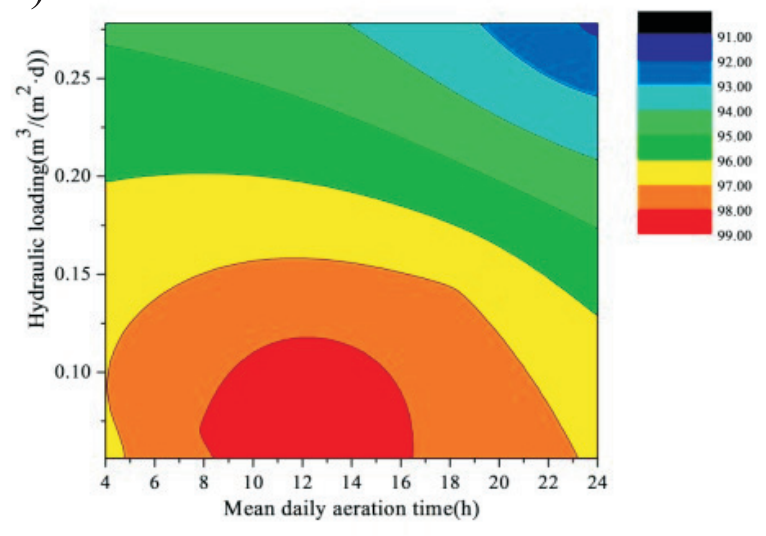

Fig. 4. Simulated diagram of removal effects of ammonia nitrogen in relation to horizontal zeolite constructed wetland. that the rate of denitrification was significantly reduced. In summary, the added bottom aeration device was not conducive to horizontal flow wetland systems for wastewater removal of total nitrogen.

In summary, the removal rates for ammonia nitrogen increased in the horizontal subsurface constructed wetland after adding the bottom aeration device. In contrast, the removal effect of total nitrogen decreased to a certain extent under this condition.

\section{Measurement of Optimal Operation Parameters under Aeration Conditions}

In this study, According to the different average daily aeration times and hydraulic loadings, namely the average daily aeration times were $4 \mathrm{~h}, 8 \mathrm{~h}, 12 \mathrm{~h}, 18$ $\mathrm{h}$, and $24 \mathrm{~h}$, and hydraulic loadings were $0.278 \mathrm{~m} / \mathrm{d}$, $0.139 \mathrm{~m} / \mathrm{d}, 0.093 \mathrm{~m} / \mathrm{d}, 0.070 \mathrm{~m} / \mathrm{d}$, and $0.056 \mathrm{~m} / \mathrm{d}$, respectively. Therefore, the objective of this study was to examine the effects of aeration on the removal effects of the horizontal subsurface constructed wetland in different conditions and present the results in 2D and 3D contour plots, then the optimal operation conditions could be obtained under aeration conditions.

a)

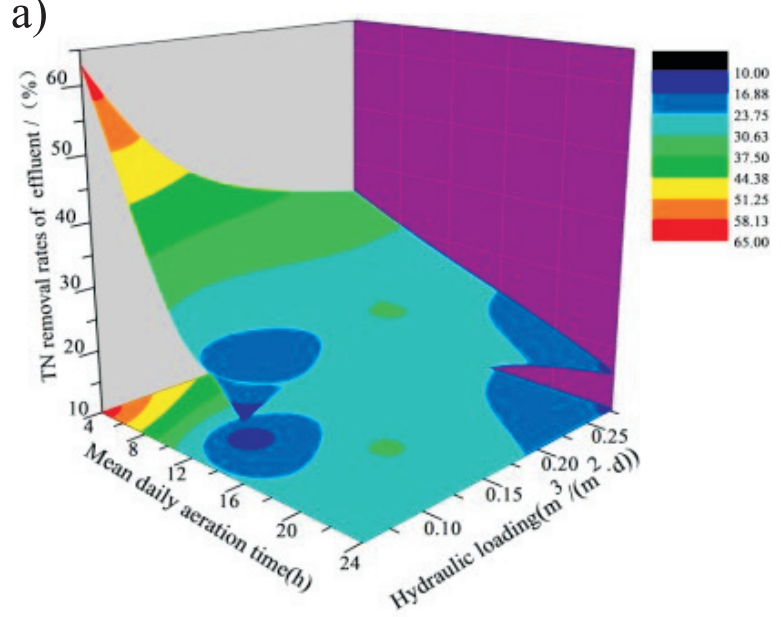

b)

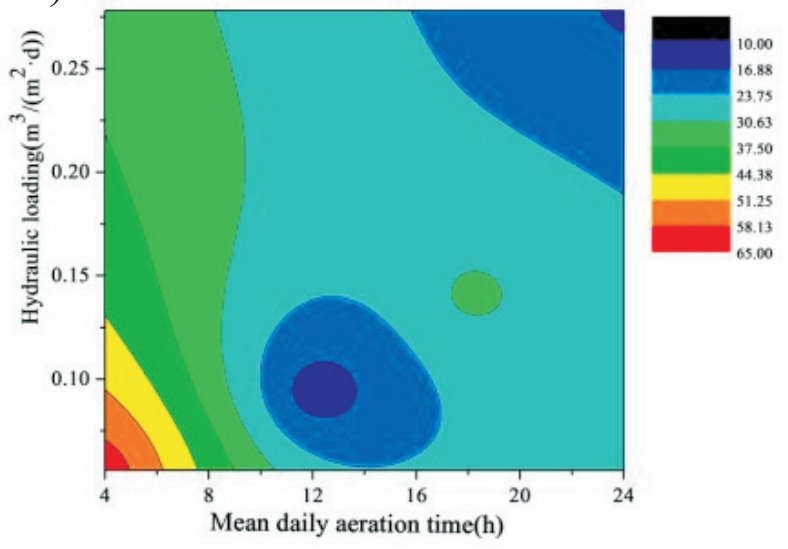

Fig. 5. Simulated diagram of removal effects of total nitrogen in relation to horizontal zeolite constructed wetland. 


\section{Optimal Operation Conditions in HZSW}

As shown in Fig. 4, under different average daily aeration times and hydraulic loadings, the removal effects of ammonia nitrogen of wastewater were obvious in HZSW. And when the indication colors were blue - which indicated that the removal effects of total nitrogen were closing up the rear when the average daily aeration time was more than $20 \mathrm{~h}$ and hydraulic loadings were more than $0.23 \mathrm{~m}^{3} /\left(\mathrm{m}^{2} \cdot \mathrm{d}\right)$ - the value of removal rates was less than $93 \%$. In contrast, the optimal removal rates for ammonia nitrogen were obtained when the average daily aeration time was about $7-17 \mathrm{~h}$ and hydraulic loadings were $0.05-0.20 \mathrm{~m}^{3} /\left(\mathrm{m}^{2} \cdot \mathrm{d}\right)$, and the removal rates could reach more than $98 \%$. In addition, the indication colors were gradually changed from deep blue to deep red in the indicated range (namely removal rates for ammonia nitrogen exhibited an inverse relationship to hydraulic loadings). For an average daily aeration time, the optimal operation conditions could also be obtained at a certain range.

As shown in Fig. 5, under different average daily aeration time and hydraulic loadings, the removal effect of total nitrogen of wastewater was not favorable in HZSW. Meanwhile, increasing average daily aeration time and hydraulic loading could apparently depress the removal effects of total nitrogen. In addition, the indication

a)
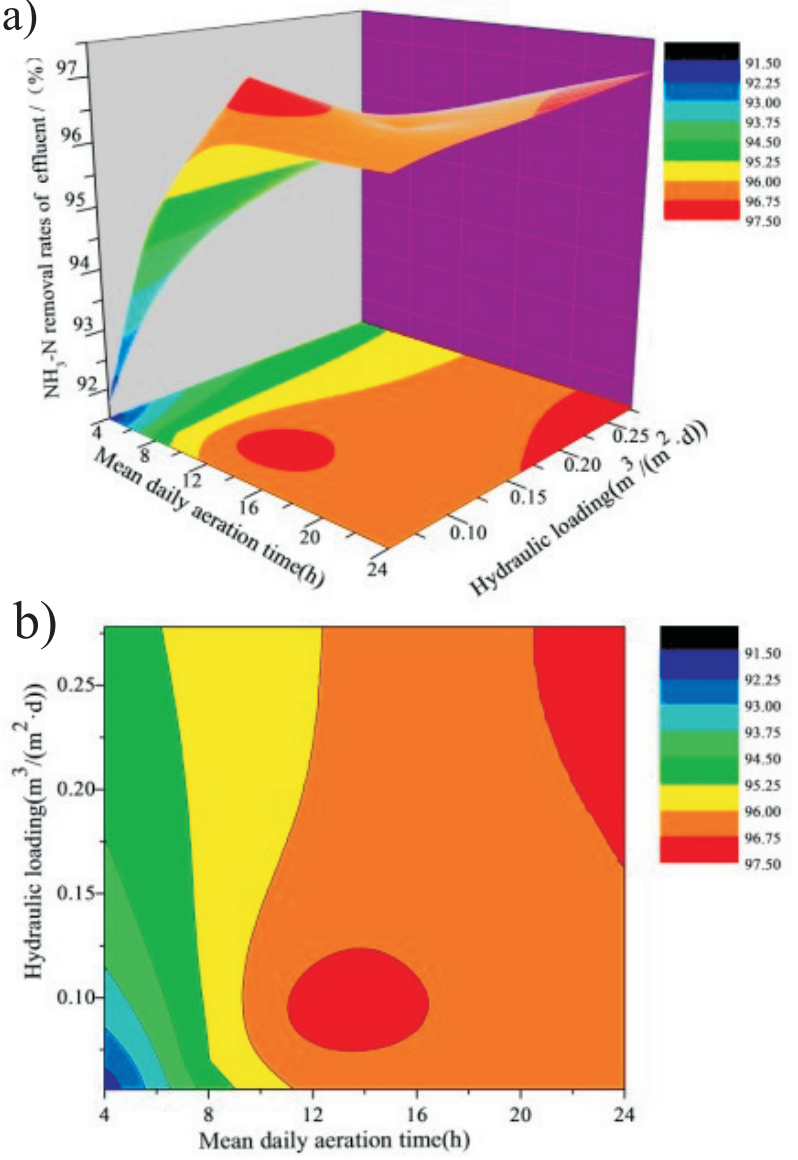

Fig. 6. Simulated diagram of removal effects of ammonia nitrogen in relation to horizontal limestone constructed wetland. colors were deep blue, which indicated that the removal effects of total nitrogen were closing up the rear when the average daily aeration time was about $11-14 \mathrm{~h}$ and hydraulic loadings were $0.05-0.20 \mathrm{~m}^{3} /\left(\mathrm{m}^{2} \cdot \mathrm{d}\right)$ or average daily aeration time $22-24 \mathrm{~h}$ and hydraulic loadings $0.37-0.45 \mathrm{~m}^{3} /\left(\mathrm{m}^{2} \cdot \mathrm{d}\right)$, and the value of removal rates was less than $19.20 \%$. In contrast, the optimal removal effects of total nitrogen were obtained when the average daily aeration time was less than $5 \mathrm{~h}$ and the hydraulic loadings were less than $0.11 \mathrm{~m}^{3} /\left(\mathrm{m}^{2} \cdot \mathrm{d}\right)$ - namely the indicated color was deep red, and the range of removal rates was about $56.40-62.60 \%$.

\section{Optimal HLSW Operational Conditions}

As shown in Fig. 6, the removal effects of ammonia nitrogen of wastewater were obvious in HLSW under different average daily aeration times and hydraulic loadings. However, compared with HZSW the average removal rates decreased to a certain extent. Meanwhile, the optimal removal rates for ammonia nitrogen in HLSW could be obtained when the average daily aeration time was more than $11 \mathrm{~h}$ and hydraulic loadings were $0.10-0.45 \mathrm{~m}^{3} /\left(\mathrm{m}^{2} \cdot \mathrm{d}\right)$, and the range of removal rates was 96.44-97.10\%. Contrary to HZLM, the indication colors were gradually changed from deep red to deep blue in

a)

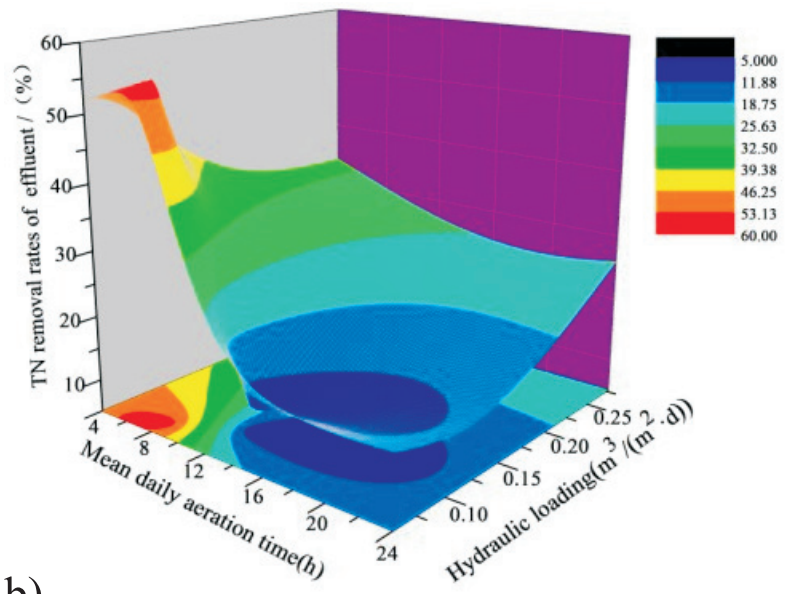

b)

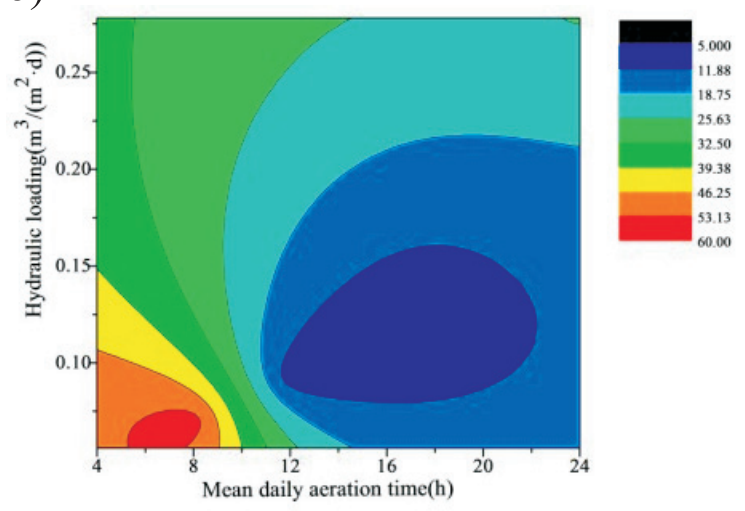

Fig. 7. Simulated diagram of removal effects of total nitrogen in relation to horizontal limestone constructed wetland. 
the indicated range (namely removal rates for ammonia nitrogen exhibited a direct proportional relationship to hydraulic loadings). For an average daily aeration time, the optimal operation condition could also be obtained at a certain range.

As shown in Fig. 7, similar to HZSW, the removal effects of total nitrogen of wastewater were not favorable in HLSW under different average daily aeration times and hydraulic loadings. Meanwhile, increasing average daily aeration time and hydraulic loading could also apparently depress the removal effects of total nitrogen. In addition, the indication colors were deep blue, which indicated that the removal effects of total nitrogen were closing up the rear when the average daily aeration time was about $12-23 \mathrm{~h}$ and hydraulic loadings were $0.12-0.27 \mathrm{~m}^{3} /\left(\mathrm{m}^{2} \cdot \mathrm{d}\right)$, and the value of removal rates was less than $14.75 \%$, which was lower than HZSM. In contrast, the optimal removal effects of total nitrogen were obtained when the average daily aeration time was less than $8.5 \mathrm{~h}$ and the hydraulic loadings were less than $0.13 \mathrm{~m}^{3} /\left(\mathrm{m}^{2} \cdot \mathrm{d}\right)$; namely, the indicated color was deep red, and the range of removal rates was 49.25-55.00\%, which was also lower than HZSM.

\section{Conclusions}

In this experiment, the bottom aeration device was applied to obtain outstanding removal rates of nitrogen in cold climate. The result showed that the optimal removal rates for major eutrophication pollution from lightly polluted wastewater in two horizontal subsurface constructed wetlands could be obtained under certain aeration times and hydraulic loadings. Furthermore, in HZSW and HLSW, the removal rates of ammonia nitrogen could achieve $98 \%$ and $97.10 \%$, and the removal rates of total nitrogen could achieve $62.6 \%$ and $55 \%$, respectively. In addition, the removal effects of ammonia nitrogen increased obviously and total nitrogen depressed apparently after being added to the bottom of the aeration device.

\section{Acknowledgements}

We gratefully acknowledge the financial support for this research from the Youth Foundation of Hebei Educational Committee (QN2015197), the Hebei Province Science and Technology Project (15273601D), and the Tangshan Science and Technology Project (13130203b).

\section{References}

1. COBAN O., KUSCHK P., KAPPELMEYER U., SPOTT O., MARTIENSSEN M., JETTEN M. S., KNOELLER K. Nitrogen transforming community in a horizontal subsurfaceflow constructed wetland. Water Res. 74, 203, 2015.

2. MURPHY C., WALLACE S., KNIGHT R., COOPER D., SELLERS T. Treatment performance of an aerated con- structed wetland treating glycol from de-icing operations at a UK airport. Ecol. Eng. 80, 117, 2015.

3. CALHEIROS C. S., QUITÉRIO P. V., SILVA G., CRISPIM L. F., BRIX H., MOURA S. C., CASTRO P. M. Use of constructed wetland systems with Arundo and Sarcocornia for polishing high salinity tannery wastewater. J. Environ. Manage. 95 (1), 66, 2012

4. YE F., LI Y. Enhancement of nitrogen removal in towery hybrid constructed wetland to treat domestic wastewater for small rural communities. Ecol. Eng. 35 (7), 1043, 2009.

5. ZHANG C. B., WANG J., LIU W. L., ZHU S. X., GE H. L., CHANG S. X., GE Y. Effects of plant diversity on microbial biomass and community metabolic profiles in a full-scale constructed wetland. Ecol. Eng. 36 (1), 62, 2010.

6. MATAMOROS V., SALVADÓ V. Evaluation of the seasonal performance of a water reclamation pond-constructed wetland system for removing emerging contaminants. Chemosphere, 86 (2), 111, 2012.

7. AYAZ S. C., AKTAŞ Ö., FINDIK N., AKÇA L., KINACI C. Effect of recirculation on nitrogen removal in a hybrid constructed wetland system. Ecol. Eng. 40, 1, 2012.

8. TROMP K., LIMA A. T., BARENDREGT A., VERHOEVEN J. T. Retention of heavy metals and poly-aromatic hydrocarbons from road water in a constructed wetland and the effect of de-icing. J. Hazard. Mater. 203, 290, 2012.

9. REDMOND E. D., JUST C. L., PARKIN G. F. Nitrogen removal from wastewater by an aerated subsurface-flow constructed wetland in cold climates. Water Environ. Res. 86 (4), 305, 2014.

10. KATO K., INOUE T., IETSUGU H., SASAKI H., HARADA J., KITAGAWA K., SHARMA P. K. Design and performance of hybrid constructed wetland systems for high-content wastewater treatment in the cold climate of Hokkaido, northern Japan. Water Sci. Technol. 68 (7), 1468, 2014.

11. WANG F., LIU Y., MA Y., WU X., YANG, H. Characterization of nitrification and microbial community in a shallow moss constructed wetland at cold temperatures. Ecol. Eng. 42, 124, 2012.

12. DONG H., QIANG Z., LI T., JIN H., CHEN W. Effect of artificial aeration on the performance of vertical-flow constructed wetland treating heavily polluted river water. J. Environ. Sci. 24 (4), 596, 2012.

13. MURPHY C., WALLACE S., KNIGHT R., COOPER D., SELLERS T. Treatment performance of an aerated constructed wetland treating glycol from de-icing operations at a UK airport. Ecol. Eng. 80, 117, 2015.

14. HU Y., ZHAO Y., ZHAO X., KUMAR J. L. High rate nitrogen removal in an alum sludge-based intermittent aeration constructed wetland. Environ. Sci. Technol. 46 (8), 4583, 2012

15. CHAZARENC F., GAGNON V., COMEAU Y., BRISSON J. Effect of plant and artificial aeration on solids accumulation and biological activities in constructed wetlands. Ecol. Eng. 35 (6), 1005, 2009.

16. MALTAIS-LANDRY G., MARANGER R., BRISSON J., CHAZARENC F. Nitrogen transformations and retention in planted and artificially aerated constructed wetlands. Water Res. 43 (2), 535, 2009.

17. LIU L., ZHAO X., ZHAO N., SHEN Z., WANG M., GUO Y., XU Y. Effect of aeration modes and influent $\mathrm{COD} / \mathrm{N}$ ratios on the nitrogen removal performance of vertical flow constructed wetland. Ecol. Eng. 57, 10, 2013.

18. FAN J., ZHANG B., ZHANG J., NGO H. H., GUO W., LIU F., GUO Y. Y., WU H. Intermittent aeration strategy to enhance organics and nitrogen removal in subsurface flow constructed wetlands. Bioresour. Technol. 141, 117, 2013. 